\title{
Major Obstacles to Economic Engines: Myths \& Realities in Pakistan
}

\author{
Saima Akhtar Syed Shoeb Ahmed Seema Khalid \\ Dept. of Public Administration, University of Karachi.
}

\begin{abstract}
SMEs are the engines for economic growth all over the world so as in Pakistan. One simply cannot overlook the importance of SMEs in struggling economy of Pakistan. Apparently access to finance is normally considered to be the most important variable in the development of the SMEs sector throughout the world but there are some other variables also which hinders the growth of these economic engines. In Pakistan although several steps have been taken by the government in development and encouraging the SMEs like creation of Small and Medium Enterprises Development Authority (SMEDA), SME bank and several small/medium business loan products by conventional and Islamic banks, etc. but still we could not reach to the full capacity of its utilization. This is a descriptive or qualitative research which is based on the secondary data taken by the survey on enterprise growth constraint by World Bank. It seems that there is a need to look for the hidden causes other than the economy which hamper SMEs to foster to its full potential in Pakistani industry. The paper in an attempt to highlight these causes which may include energy and power crises, corruption, court system, law and order situation, transportation, unskilled labor force etc.
\end{abstract}

Keywords: SMEs; Economic Engine; Pakistan; Enterprise Survey; World Bank; Biggest Obstacle to firms.

DOI: $10.7176 / \mathrm{JESD} / 10-6-16$

Publication date:March $31^{\text {st }} 2019$

\section{LITERATURE REVIEW}

Definition of SME

The definition of Small and Medium Enterprise (SME) varies from institution to institution and country to country even calendar has an impact upon the definition of SME. Following are some view of SME in the context of Pakistan.

$>$ SME policy 2017:

According to SME policy 2017, SME is the organization which employs up to 250 people, having paid up capital of up to PKR 25 million and annual sales turnover up to PKR 250 million (MoIP, GoP, 2007).

\section{$>$ State Bank of Pakistan:}

According to State Bank of Pakistan (SBP), Small Enterprises (SEs) are the organizations which employ up to 50 persons, can be extended finances up to PKR 25 million and annual sales turnover up to PKR 150 million and Medium Enterprises (MEs) are the business entities which employ 50 to 250 people, can be extended finances between PKR 25 to 200 million and annual sales turnover between PKR 150 million to PKR 800 million (SBP, 2016).

\section{Background}

SMEs play a vital role in the socio-economic development of Pakistan. According to Census of Establishments conducted by the Federal Bureau of Statistics (FBS), there are $90 \%$ SMEs out of all the business entities in Pakistan; which employ $78 \%$ of all non-agriculture labor force and it contributes $30 \%$ in the GDP of Pakistan (Zafar \& Mustafa, 2017). According to SMEDA, SMEs share currently in Pakistan's GDP is 40\% (SMEDA, 2017).

Statistic clearly shows the importance of SME sector in Pakistan which drew the Government of Pakistan's attention to consider SME as the four pillars to economic revival plan presented in 1999 to 2000 . Government of Pakistan created the Task Force for SME Policy Development in 2004 whose responsibilities were to develop a SME policy for the development and encouragement of SME sector in Pakistan. As a result, SME Policy came into existence in 2007 through the participation of thousands of SMEs throughout the Pakistan.

\section{$>$ SMEDA:}

Government of Pakistan (GoP) created the Small and Medium Enterprise Development Authority (SMEDA) in 1998 for the development and encouragement of SMEs in Pakistan. It comes under the Ministry of Industries and Production. SMEDA does not only serve as a policy-advisory body to the GoP but also acts as a facilitator to the other stakeholders for the development of SMEs in Pakistan. Some of objectives of SMEDA is to formulate a policy, to identify the business opportunities, to maintain databases for SMEs, to provide assistance to SMEs for securing the access to finance etc.

SMEDA had been a good step toward the development of SMEs culture but its ability to withstand political policy changes was weak. In the absence of complete SME policy framework SMEDA, a single organization, was unable to take strong initiatives because SMEs related issues fall within the horizon of number of ministries at 
both federal and provincial level. And unfortunately, SMEDA does not have linkages to these institutions.

Due to the lack of finance or capital, SMEDA with limited number of people and scarce resources was unable to take capital intensive initiative for the development of SMEs which led the creation of SME Bank Ltd.

\section{SME Bank:}

SME Bank Ltd. was established by the Government of Pakistan as a result of merger of the Regional Development Finance Corporation (RDFC) and Small Business Finance Corporation (SBFC) in 2002 for the purpose of serving SMEs only. SME Bank got the commercial bank license in 2004 and commenced its operation from 2005. Government of Pakistan is the leading shareholder having (92.68\%) while six banks having (7.32\%) in SME Bank Ltd. (Tatiana Nenova, 2009). The SME Bank primarily focusses upon the 'access to finance' issue faced by the SMEs to stimulate growth and development of SME sector.

The objectives of SME Bank Ltd. are the following (SME Bank Ltd., 2016):

i. $\quad$ To support the SMEs by providing technical and financial assistance.

ii. To support SMEs to contribute to the economic growth by value addition and export.

iii. To support SMEs to foster entrepreneurial culture in the economy by reducing poverty and creating jobs (SME Bank Ltd., 2016).

In-spite of these measures, SME Bank is unable to cope up with the finance needs required by the SMEs because of its inappropriate product design, traditional and lengthy procedures for securing credit (It takes almost 40 days to obtain the credit) and inefficient human resource policy to hire 18 loan officers in 27 branches (Tatiana Nenova, 2009).

SME Bank performance was not up to the mark and it could not perform efficiently as compared to the same institutions in other countries (Table 1). Same institutions in other countries like Bangladesh and Ukraine, who came into existence in 1999 and 2001, have been performing better than the SME Bank Pakistan which was created in 2002. Their total assets in USD are 676.1 million and 454 million respectively. Number of loan officers in Bangladesh is 1369 and in Ukraine is 246 as compared to 18 in SME bank Pakistan. The $72 \%$ of gross loan in volume of SME Bank Pakistan is considered to be lost as compared to $18 \%$ and $0.98 \%$ of Bangladesh and Ukraine respectively.

Table 1

\begin{tabular}{|c|c|c|c|c|}
\hline \multicolumn{5}{|c|}{ Results for Selected Small Business Banks (December 2007) } \\
\hline & $\begin{array}{l}\text { Pro Credit } \\
\text { Ukraine }\end{array}$ & $\begin{array}{c}\text { BancoSol } \\
\text { Bolivia }\end{array}$ & $\begin{array}{c}\text { BRAC Bank } \\
\text { Bangladesh }\end{array}$ & $\begin{array}{l}\text { SME Bank } \\
\text { Pakistan }\end{array}$ \\
\hline Total assets (million \$) & 454 & 269.9 & 676.1 & 107.4 \\
\hline Year of establishment & 2001 & 1992 & 1999 & 2002 \\
\hline Number of outlets or branches & 71 & 49 & $\begin{array}{c}\text { Branches: } 36 \\
\text { SME unit } \\
\text { offices: } 392\end{array}$ & 27 \\
\hline Number of loan officers & $246^{*}$ & $297^{*}$ & 1,369 & 18 \\
\hline Average time to disburse a loan (days) & 5 & 5 & 15 & 40 \\
\hline Gross loan portfolio (million in \$) & 389.2 & 209 & 473.2 & 126.6 \\
\hline Average loan size outstanding (in \$) & 7,358 & 2,360 & 4,067 & $13,703 * *$ \\
\hline Portfolio at risk (PAR) $>30$ days & $0.98 \%$ & $1 \%$ & $18 \%$ & $72 \% * * *$ \\
\hline Total assets for holding/fund (in \$) & 6 billion & 140.3 million & 2.4 billion & Not Applicable \\
\hline
\end{tabular}

\section{$>$ SME Task Force:}

To make a proper policy framework for the development of SMEs or to generate a consensus among all stakeholders, Government of Pakistan (GoP) established the SME Task Force for the development of SME Policy in January 2004 at the Ministry of Industries \& Production. SMEDA will bear the responsibilities to act as the secretariat. The Task Force consists of major private stakeholders and government officials.

Following are the objectives of SME Task Force according to SME Policy 2007:

- "Achieve discrete policy and regulatory space for SMEs along with identification of key areas for reforms concerning laws, regulations, and programs.

- Develop SME Policy identifying roles of Federal, Provincial and Local Governments and private \& public sectors in SME sector development.

- Define principles of SME support and set priorities.

- Institutionalize SME support to ensure regular information sharing among Federal, Provincial, Local Governments and SMEs.

- Propose detailed processes and time bound action and resource requirement for SME sector development 
and support programs.

- Propose separate economic indicators to institute monitoring and evaluation mechanisms for SME Policy and Programs.

- Propose a National Level Authority to coordinate activities for SME development." (MoIP, GoP, 2007)

SME Task Force consists of 4 Working Committees to work upon the following areas:

i. Business Environment: which is one of the most important area to work on when it comes to Pakistan, according to survey on enterprise growth constraint by World Bank, which will be discussed later on in this article.

ii. Access to Finance: to help SMEs secure finance.

iii. Access to Resources and Services: to provide SMEs the qualified human resources, technology, and other development services.

iv. SME Definition, Feedback \& Monitoring Mechanism: to devise a common acceptable definition of SME which consists of Micro, Small, Medium, and Large enterprises by all the institutions. And the establishment of a system through which the effectiveness of these services provided to SMEs can be monitored.

\section{SME Policy 2007:}

SME Policy was approved by The Federal Cabinet of Pakistan on January 17, 2007 as a result of working and consideration of SME Task force and its four Working Committees. SMS Policy 2007 was created with the process of participation of more than thousands of SMEs, chamber of commerce and industries, public sector organization, trade association and private sector bodies (SME Policy 2007).

According to SME Policy 2007, the objective of the SME Policy is:

- To establish a separate policy and regulatory framework for short to long term with the

- To provide a single definition of SMEs.

- To establish measures to eradicate the disfavor of size.

- To minimize the regulatory requirements to reduce the cost of doing business.

- To establish a support system for SMEs.

- To improve support delivery mechanism.

- To create policy evaluation and review systems.

SME Policy envisions to increase the number of manufacturing small enterprises, decreasing the cost of doing business by reducing the regulations, and increasing the share of women ownership. Numerous measures have been taken to ensure the implementation of the objectives mentioned above including the SME Support Fund and creating a business-friendly environment.

\section{PROBLEM STATEMENT}

The economic performance of Pakistan is very much linked with the performance of SMEs as SME sector contributes $40 \%$ in the GDP of Pakistan. Although some measures have been taken by the government to support SME sector by establishing SMEDA, SME Bank, SME Task Force, and SME Policy 2007 but Pakistan could not utilize its SME sector to its full capacity (Berry, 1998). According to (Bhutta, Khan, Omer, \& Asad, 2009), the performance of Pakistan's SME sector is not on the way that should have been.

It seems like government's policies and mechanism are not sufficient to let the SMEs sector foster. Some other variables should also be taken care of by the government.

According to World Bank Group's report titled 'Doing Business 2017: Equal Opportunity for All', Pakistan ranked 144 out of 190 counties in ease of doing business (World Bank Group, 2017).

\footnotetext{
ANALYSIS

In this paper, our emphasis is on the other causes which is considered to be the real obstacles in the growth of SMEs culture in Pakistan despite the government taking measures, as mentioned in the literature review. According to Survey on Enterprise Growth Constraint by World Bank, some other variables (causes) has also been highlighted by the entrepreneurs in Pakistan which are considered to be the most important in the local condition than the access to finance.

\section{Enterprise Survey (ES):}

Enterprise Survey (ES) is a firm-based survey for the private sector of the economy. It covers the areas of business environment such as competition, access to finance, crime, corruption, infrastructure, gender, and performance measures. World Bank collects the data through face-to-face interviews of entrepreneurs and top-executives in over 130,000 companies in 135 countries (World Bank Group, 2015).
} 


\section{Enterprise Survey (ES) of Pakistan':}

This section summarizes the ES survey data for Pakistan which was taken in between 2013 to 2015 by the World Bank, according to which 1,247 firms' owners and top-executives were interviewed (World Bank Group, 2015).

These firms were surveyed in Pakistan from all of the four provinces and the capital territory which consists of 668 firms from Punjab, 215 from Sindh, 212 from KPK, 91 from Islamabad and 61 from Baluchistan. These firms were of different in sizes which includes 509 small enterprises along with 471 medium and 267 large enterprises. 29 were from Motor Vehicles and Transport Equip, 38 from Retail, 86 from Garments, 111 from Chemicals and Chemical Products, 123 from Other Services, 141 from Non-Metallic Mineral Products, 167 from Textiles, 233 from Food, and 319 from Other Manufacturing (World Bank Group, 2015).

When entrepreneurs and top-executives of these firm were asked to choose the biggest obstacle to their business among the list of 15 business environments obstacles ${ }^{2}$, owners or top-executives of 45.3 percent of firms chose electricity as the biggest obstacle to their business. 17.3 percent chose corruption, 8.7 percent chose political instability, 6.8 percent chose tax administration, 6.2 percent chose crime and disorder (law and order), 3.6 percent chose tax rates, 3.1 percent chose poorly educated workers, 2.7 percent chose access to finance, 2.4 percent chose trade regulations, and 1.7 percent chose transportation as the biggest obstacle to their business (World Bank Group, 2015).

Following are the individual analyses of these obstacles (causes) according to the list of ' 15 business environments obstacles.

$>$ Corruption:

According to the survey, 17.3 of firms chose corruption as the biggest constraint to enterprise growth. Following are the indicators which were experienced by the firms:

- $30.8 \%$ of organizations are those who faced at least one bribe request.

- $28.8 \%$ of organizations are those who expected to offer gifts in meetings with tax authorities.

- $88.2 \%$ of organizations are those who expected to offer gifts to get government contracts.

- $\quad 31 \%$ of organizations are those who expected to offer gifts to have an operating license.

- $28.7 \%$ of organizations are those who expected to offer gifts to have a construction permit.

- $57.8 \%$ of organizations are those who expected to offer gifts to have an electrical connection.

- $30.9 \%$ of organizations are those who expected to offer gifts to have water connection.

- $45.8 \%$ of organizations are those who expected to offer gifts "to get the thing done".

- $68.3 \%$ of organizations ranked corruption as the major constraint.

- $\quad 34.6 \%$ of organizations considered the court system as the major constraint.

The above date showed that organizations have to bear an additional cost in terms of bribery to secure contracts, operating license, construction permit, electrical connection, water connection, etc. which increases the cost of doing business in Pakistan.

$>$ Crime:

$6.2 \%$ of firms considered crime and disorder as the biggest constraint among 15 business environment obstacles. The indicators according to ES data are the following:

- Improper law and order situation made $51.7 \%$ of organization to pay for their own security in the form of security equipment, personnel, or professional security services.

- $9.5 \%$ of organization facing losses in the form of theft, robbery, vandalism or arson.

- $34.1 \%$ of organization considering crime, theft or improper law and order situation as the major constraint. Similarly the factors like improper law and order situation in the country which includes theft, robbery, vandalism etc. have also been increasing the cost of doing business in Pakistan because organizations have to pay for their own security in the form of private security services, equipment etc.

$>$ Finance:

Access to finance is generally considered to be the most important obstacle but as far as Pakistan is concerned, only $2.7 \%$ of organizations considered it to be the biggest obstacle to enterprise growth. Following are the indicators.

- $\quad 57 \%$ of organizations are those who did not apply for a loan in the last fiscal year because they did not need a loan.

- $87.6 \%$ of fixed assets were financed from internal funds/retained earnings.

- $13.2 \%$ of organizations considering access to finance as the major constraint to growth.

According to the data mentioned above, majority of firms did not apply for the loan because they did not need it and they have been financing largely from their retained earnings, which gives 'access to finance' less importance as compared to other factors which hinders the growth of SMEs in Pakistan.

\footnotetext{
${ }^{1} \mathrm{http}: / /$ www.enterprisesurveys.org/data/exploreeconomies/2013/pakistan

${ }^{2}$ https://www.enterprisesurveys.org
} 
$>$ Firm Characteristics:

Following are the indicators:

- $73.8 \%$ of organizations has a legal status of Sole Proprietorship

- $\quad 35.8 \%$ of organizations have internationally-recognized quality certification, i.e. ISO 9000, 9002 or 14000 .

- $\quad 37.5 \%$ of organizations are those whose annual financial statements are reviewed by external auditors.

Majority of organizations has been operating as a sole proprietorship. Only one-third of the organizations have internationally-recognized quality certification which make their product less attractive in foreign markets.

\section{$>$ Gender:}

Following are the indicators:

- $11.8 \%$ of organizations are those in which female participates in ownership.

- $8 \%$ of organizations are those in which female ownership is greater than $50 \%$.

- $6 \%$ of organizations are those in which top manager is female.

Female ownership is very limited in organizations. Few of them is in the top management of the organization.

$>$ Informality:

Following are the indicators:

- $46.5 \%$ of organizations are those competing with unregistered or informal firms.

- $79.8 \%$ of organizations are those who officially got registered when they started operations in Pakistan.

- $13.1 \%$ of organizations are those considering the major constraint as the practices of competitors in the informal sector.

Firms facing the practices of competitors those which are not registered in the informal sector as the major constraint.

\section{Infrastructure:}

$45.3 \%$ of organizations considered electricity or energy shortage as the biggest obstacle to enterprise growth. Following are the indicators:

- $81.1 \%$ of organizations facing electrical outages.

- $33.8 \%$ of total annual sales on average is reported to be losses as a result of electrical outages, if any.

- $65.4 \%$ of organizations reported to be having or using a generator.

- It takes 82.8 days to obtain an electrical connection from the day this establishment applied for it to the day it received the service.

- $75.3 \%$ of organizations considering electricity as the major constraint.

- $10.5 \%$ of organization facing water shortages during the previous fiscal year.

- $25.5 \%$ of organization considering transportation as the major constraint to growth and $1.7 \%$ of organization reported transportation as the biggest obstacle among 15 business environment obstacles.

Almost every organization experiencing power outages due to which their annual sales is reported to be losses. Almost two-third of the organizations have generators. Other factors including the water shortages and transportation also increase the cost of doing business in Pakistan. Electricity is reported to be the biggest obstacle among 15 business environment obstacles by majority of firms.

\section{Innovation and Technology:}

Following are the indicators:

- $21.1 \%$ of organizations are those using technologies licensed from foreign companies.

- $46.9 \%$ of organizations are those who have their own website.

- $\quad 54.5 \%$ of organizations are those who use email to communicate with clients.

- $\quad 19.8 \%$ of organizations are those spend on R\&D.

Almost one-half of the organizations have their own website and use email as a medium of communication. More than two-third of organizations are those who do not spend of R\&D which hinders their future growth.

\section{$>$ Performance:}

The performance indicators to the firms are the following:

- Capacity utilization is $76.8 \%$ which is based on the comparison of the current output with the maximum output possible using all the resources available.

- Annualized growth is $5.4 \%$ of permanent full-time workers.

Organization are unable to reach their full capacity of utilization which is one of the constraint toward profitability and growth.

\section{$>$ Regulations and Taxes:}

According to ES by World Bank, $6.8 \%$ of firms considered tax administration and $3.6 \%$ of firms considered tax rates as the biggest obstacle among 15 business environment obstacles listed by ES. Following are the indicators 
for regulation and taxes:

- $65.6 \%$ of organizations are required to meet with tax authorities.

- It takes 10.4 days to get the operating license from the day the establishment applied for it to the day it was granted.

- It takes 33.6 days on average to get a construction-related permit from the day the establishment applied for it to the day it was granted.

- It takes almost 33.5 days to get an import license from the day the establishment applied for it to the day it was granted.

- $54.1 \%$ of organizations are those considering tax rates as the major constraint.

- $34.1 \%$ of organization are those considering the major constraint as the tax administration.

- $24.5 \%$ of organization are those considering the major constraint as business licensing and permits.

Organizations find it difficult and time consuming to get operating license, construction related permit, import license etc. which slow their growth along with the other factors which included tax rates and tax administration

$>$ Trade:

$2.4 \%$ of firms considered trade regulations as the biggest obstacle among 15 business environment obstacles by ES. Following are the indicators:

- It takes almost 11.4 days on average to clear direct exports through customs.

- $18 \%$ of organizations are those exporting at least $10 \%$ of their total annual sales directly or indirectly.

- $12.6 \%$ of organizations are those exporting at least $10 \%$ of their sales directly.

- It takes 12.7 days on average to clear imports from customs.

- $21.4 \%$ of firms considering customs and trade regulations as the major constraint to enterprise growth. Trade regulations is reported to be cumbersome and time consuming which takes time to clear the direct export and import which decreases the ease of doing business in Pakistan.

$>$ Workforce:

$3.1 \%$ of firms chose poorly educated workers as the biggest obstacle among 15 listed business environment obstacles by ES. Following are the indicator:

- $32 \%$ of organizations are those offering formal training to their employees.

- $12.9 \%$ of organizations are those considering labor regulations as the major constraint.

- $24.2 \%$ of organizations are those considering poorly educated workforce as the major constraint.

Only one-third of the organizations offer formal training to their employees. While labor regulations and unskilled labor force is thought of as the major constraint to the growth of the firm.

\section{CONCLUSION}

Like most of the developing countries, SMEs are the engines for economic growth in Pakistan as it contributes $40 \%$ to the GDP and $80 \%$ of non-agriculture labor force. Government has taken a number of measures to support the SME sector by establishing the SMEDA, SME Bank, SME Policy 2007 etc. but Pakistan still could not utilize its SMEs to its full potential or could not reach to its full capacity.

Usually the major constraint to the growth of SMEs in the world is normally considered to be the access to finance but when it comes to Pakistan, some other causes which also hinders the growth of SMEs more than the finances. Upon deep analysis we can conclude that the bad governance is the major cause of the failure of proper SMEs framework. Issues of governance like electricity, corruption, law and order (rule of law), transportation, political instability along with mal administration and improper public policies like feeble tax administration and utilization, unrationalized tax rates, unclear trade regulation and less skilled resources as compared to access to finance are the major reasons of lack of trust by the firms in establishing the small business.

\section{POLICY RECOMMENDATION}

Following are some of the recommendations which can support the SMEs in Pakistan which can be a great contributor towards stable economy of the country.

$>$ Government should take some additional measures to curb the power outages which is considered by most of organizations as the biggest obstacle to firms in Pakistan.

$>$ Corruption should be reduced and rule of law should prevail to enhance the operations of the business profitably with less "speed money".

> Ample arrangements for logistics, warehousing and other supply chain activities must be done in affordable packages and with ease.

$>$ Political stability is extremely important for the organization to come. People will start investing in business if political stability is there. Political instability raises panic among investors to withdraw their investment to keep it in safe heavens.

$>$ Firms bearing a cost of installing additional security measures by their own due to the improper law and order situation deteriorating day by day, increasing the cost of doing business in Pakistan. 
$>$ Curriculum should be revised as per the need of firms along with proper vocational training programs which should be offered by the government to foster skilled labor force. The gap between academic institutions and business should be reduced.

Finally based on our research findings, government needs to take some emergency actions to improve good governance. A comprehensive and sustainable policy framework is needed by the government to address these issues.

Implementing the above suggestions will provide the proper framework for SMEs, through which we can change our status from DEVELOPING nation to the DEVELOPED one.

\section{Bibliography}

Berry, A. (1998). The Potential Role of the SME Sector in Pakistan in a World of Increasing International Trade. The Pakistan Development Review, 37(4).

Bhutta, M. S., Khan, J. H., Omer, A., \& Asad, U. (2009). An Exploratory Study of the Characteristics Affecting the Success of SMEs. International Journal of Entrepreneurship and Small Business.

FBS, F. B. (n.d.). Census of Establishments.

MoIP, GoP. (2007). SME Policy. SMEDA. Retrieved from http://smeda.org/files/smepolicy2007.pdf

MoIP, GoP. (2007). SME Policy 2007: SME Led Economic Growth - Creating Jobs and Reducing Poverty. SMEDA. Retrieved from http://www.smeda.org.pk

SBP. (2016, May 6). Infrastructure, Housing \& SME Finance Department. Retrieved from http://www.sbp.org.pk: http://www.sbp.org.pk/smefd/circulars/2016/C2.htm

SME Bank Ltd. (2016). Retrieved from http://smebank.org/history/

SME Policy 2007. (n.d.). Government of Pakistan.

SMEDA. (2017). State of SMEs in Pakistan. Retrieved from www.smeda.org: http://www.smeda.org/index.php?option=com_content\&view=article\&id=7:state-of-smesinpakistan\&catid $=15$

Tatiana Nenova, C. T. (2009). Bringing Finance to Pakistan's Poor: Access to Finance for Small Enterprises and the underserved. Washington DC: The World Bank.

World Bank Group. (2015). Enterprise Surveys (ES). Retrieved from www.enterprisesurveys.org: http://www.enterprisesurveys.org/data/exploreeconomies/2013/pakistan\#crime

World Bank Group. (2017). Doing Business 2017: Equal Opportunity for All. Washington DC.

Zafar, A., \& Mustafa, S. (2017). SMEs and its Role in Economic and Socio-Economic Development of Pakistan. International Journal of Academic Research in Accounting, Finance and Management Sciences, 7(4), $195-$ 205. 